\title{
In Vitro and In Vivo Effects of Granulocyte Colony-Stimulating Factor on Neutrophils in Glycogen Storage Disease Type 1B: Granulocyte Colony-Stimulating Factor Therapy Corrects the Neutropenia and the Defects in Respiratory Burst Activity and $\mathrm{Ca}^{2+}$ Mobilization
}

\author{
LISA J. MCCAWLEY, HELEN M. KORCHAK, STEVEN D. DOUGLAS, DONALD E. CAMPBELL, \\ PAUL S. THORNTON, CHARLES A. STANLEY, LESTER BAKER, AND LAURIE KILPATRICK \\ Department of Pediatrics, University of Pennsylvania School of Medicine, Children's Hospital of Philadelphia, \\ Joseph Stokes Jr. Research Institute, Philadelphia, Pennsylvania 19104
}

\begin{abstract}
Children with glycogen storage disease (GSD) type $1 \mathrm{~b}$ are susceptible to recurrent bacterial infections and have chronic neutropenia accompanied by phagocytic cell dysfunction including decreased superoxide anion $\left(\mathrm{O}_{2}^{-}\right)$generation, calcium $\left(\mathrm{Ca}^{2+}\right)$ mobilization, and chemotactic activity. Granulocyte colony-stimulating factor (G-CSF), a cytokine that corrects neutropenia in other diseases, in vitro enhances f-Met-Leu-Phe-triggered neutrophil $\mathrm{O}_{2}^{-}$generation. Short-term pretreatment (15 min) of GSD $1 b$ neutrophils with G-CSF increased the rate of $\mathrm{O}_{2}^{-}$production $(p<0.01$ ) significantly below the rate of $\mathrm{O}_{2}^{-}$production in control neutrophils. Recombinant human G-CSF (5 $\mu \mathrm{g} / \mathrm{kg} / \mathrm{d})$ was administered s.c. to a GSD $1 b$ patient. Before treatment, absolute neutrophil counts were $<500 / \mathrm{mm}^{3}$. Two d after G-CSF administration, the absolute neutrophil counts increased to 1333 and remained in the normal range during a 12-mo follow-up period. In vivo, G-CSF therapy increased f-Met-Leu-Phe-stimulated $\mathrm{O}_{2}^{-}$production to $52 \%$ of control after $1 \mathrm{mo}$, and by $\mathrm{mo} 4, \mathrm{O}_{2}^{-}$production reached control levels. Our previous studies (J Clin Invest 56:196202,1990 ) demonstrated that decreased $\mathrm{O}_{2}^{-}$production in neutrophils was associated with impaired $\mathrm{Ca}^{2+}$ mobilization. In vivo administration of G-CSF increased f-MetLeu-Phe-triggered $\mathrm{Ca}^{2+}$ mobilization by neutrophils to $43 \%$ of control by mo 1 of G-CSF therapy and to $93 \%$ of control by mo 4, thus paralleling the improvements in $\mathrm{O}_{2}^{-}$ generation. In contrast, G-CSF therapy had no effect on the defective neutrophil chemotaxis. In summary, G-CSF therapy produced a rapid increase in circulating neutrophils and a gradual correction of $\mathrm{O}_{2}^{-}$production. Long-term exposure to G-CSF may be required for correction of both neutropenia and $\mathrm{O}_{2}^{-}$production in GSD $1 \mathrm{~b}$ patients. (Pediatr Res 35: 84-90, 1994)
\end{abstract}

\section{Abbreviations}

GSD, glycogen storage disease $\mathrm{O}_{2}^{-}$, superoxide anion

Received May 5, 1993; accepted September 1, 1993

Correspondence: Dr. Laurie Kilpatrick, Division of Allergy, Immunology and Infectious Diseases, Children's Hospital of Philadelphia, 34th St. and Civic Center Blvd., Philadelphia, PA 19104.

Supported in part by NIH Grants AI-24840, RR-00240, and MH 47422 and by a grant from the Ethel Brown Foerderer Fund for Excellence of the Children's Hospital of Philadelphia.
G-CSF, granulocyte colony-stimulating factor

GM-CSF, granulocyte-macrophage colony-stimulating factor

rh, recombinant human

ANC, absolute neutrophil count

PMA, phorbol myristate acetate

$\mathrm{Ca}^{2+}$, calcium

In both GSD type $1 \mathrm{a}$ and $1 \mathrm{~b}$, hepatic defects prevent the conversion of glucose-6-phosphate to glucose, resulting in hypoglycemia during fasting (1-5). In GSD la, the hepatic enzyme glucose-6-phosphatase is defective, whereas in GSD lb the glucose-6-phosphate translocase is affected. The clinical features of GSD $1 \mathrm{~b}$ are similar to those of GSD la, with the exception that GSD $1 \mathrm{~b}$ patients are often neutropenic and are prone to recurrent infections, whereas GSD la patients are not (6-11). The recurrent bacterial infections most commonly involve the skin, perirectal area, lungs, ears or urinary tract. Organisms that are most frequently isolated include Staphylococcus aureus, group A Streptococcus, Streptococcus pneumoniae, and Escherichia coli (12). Such infections usually respond poorly to treatment, and many patients require repeated, prolonged hospitalizations for i.v. antibiotics.

Critical to host defense against infections are circulating phagocytic cells, namely neutrophils and monocytes. In addition to a diminished number of circulating neutrophils, there is evidence of functional defects including depressed respiratory burst activity and chemotaxis in phagocytic cells from GSD $1 \mathrm{~b}$ patients that limit their ability to destroy invading microorganisms (8, 13-17). In previous studies, we have demonstrated decreased $\mathrm{O}_{2}^{-}$production associated with blunted $\mathrm{Ca}^{2+}$ mobilization in phagocytic cells from GSD 1b patients $(18,19)$. However, the specific phagocytic cell defect has yet to be identified.

With the discovery and cloning of growth factors such as G$\mathrm{CSF}$, new therapies have become available to neutropenic patients. G-CSF stimulates the proliferation and differentiation of committed granulocyte precursor cells [for reviews, see Dmetri and Griffin (20) and Gregory et al. (21)]. G-CSF also has specific effects on mature neutrophils. In vivo and in vitro studies have demonstrated that G-CSF enhances neutrophil functions including effects on $\mathrm{O}_{2}^{-}$generation and adherence (22-25). G-CSF itself does not generate a respiratory burst but is capable of 
enhancing $\mathrm{O}^{-}$generation in response to stimuli such as f-MetLeu-Phe $(26,27)$.

Recently, G-CSF has been used successfully in the treatment of patients with congenital and cyclic neutropenia $(28,29)$. The dual purposes of this study were 1 ) to determine whether G-CSF therapy would correct both the neutropenia and the associated functional defects of neutrophils in a patient with GSD type lb and 2) to determine the time course required for this effect.

\section{MATERIALS AND METHODS}

Case history of patient for in vivo study. The patient is a 13-yold girl with GSD $1 \mathrm{~b}$ who had chronic recurrent infections accompanied by severe neutropenia and defective neutrophil function. Since infancy, the patient has required four to six hospitalizations each year due to severe infections and complications associated with GSD $1 \mathrm{~b}$. These infections included severe mucosal ulcerations, widespread abscesses, sinusitis, gingivitis, and pneumonia. At the time of initial G-CSF trial, her ANC ranged between 220 and $480 / \mathrm{mm}^{3}$.

In vivo rhG-CSF treatment plan. Informed consent from the patient and parents was obtained in accordance with the Institutional Review Board at the Children's Hospital of Philadelphia. Under the compassionate use protocol, rhG-CSF (Amgen, Thousand Oaks, CA) was administered s.c. at a dosage of $5 \mu \mathrm{g} / \mathrm{kg} / \mathrm{d}$. Complete blood counts were obtained daily for $2 \mathrm{wk}$, weekly for the following $6 \mathrm{mo}$, and biweekly thereafter.

Study population for in vitro studies. Informed consent from the patients and parents was obtained in accordance with the Institutional Review Board at the Children's Hospital of Philadelphia. The study population consisted of four unrelated GSD $1 \mathrm{~b}$ patients: one male aged $24 \mathrm{y}$ and three females aged 4, 9, and $13 \mathrm{y}$. The 13-y-old female was excluded from the in vitro studies while receiving rhG-CSF therapy.

Neutrophil separation. Neutrophils were isolated from heparinized venous blood $\left(1 \times 10^{4} \mathrm{U} / \mathrm{L}\right)$. Standard isolation techniques were used with Ficoll-Hypaque centrifugation, followed by dextran sedimentation and hypotonic lysis to remove residual erythrocytes (30). Cells were washed twice and resuspended in PBS, pH 7.4.

Monocyte isolation. Monocytes were isolated from heparinized venous blood $\left(1 \times 10^{4} \mathrm{U} / \mathrm{L}\right)$ as previously described by Hassan et al. (31). Mononuclear cells, separated from whole blood by Ficoll-Hypaque centrifugation, were suspended in Dulbecco's modified Eagle medium. The cell suspension was plated onto gelatin-coated tissue culture flasks and incubated at $37^{\circ} \mathrm{C}$ for 45 min in $5 \% \mathrm{CO}_{2}$. Nonadherent cells were removed by washing the flasks several times. Adherent monocytes were then detached by incubation with 5 mM EDTA in Dulbecco's modified Eagle medium with $10 \%$ FCS. These cell populations were $92-96 \%$ monocytes, based on latex ingestion and nonspecific esterase staining.

Fura-2 fluorescence spectroscopy. Cytosolic free $\mathrm{Ca}^{2+}$ concentrations were determined in fura- 2 loaded neutrophils according to the method of Korchak et al. (32). Cells were incubated in 10 $\mu \mathrm{M}$ fura-2 acetoxymethyl in $N$-2-hydroxyethylpiperazine- $N^{\prime}-2$ ethanesulfonic acid buffer at $37^{\circ} \mathrm{C}$ for $5 \mathrm{~min}$. This suspension was then diluted 10-fold in buffer, incubated for $20 \mathrm{~min}$, and resuspended in fresh buffer. This loading protocol optimizes fura2 acetoxymethyl uptake and its conversion to the free acid fura2 resulting in a cell-associated concentration of $0.5 \mu \mathrm{M}$ fura- 2 . Immediately before use, cells were microfuged and resuspended at a cell concentration to $2.5 \times 10^{9}$ cells/L. Fluorescence changes were monitored in a stirred suspension of preloaded cells at dual excitation wavelengths of 340 and $380 \mathrm{~nm}$ and an emission wavelength of $510 \mathrm{~nm}$. Cytosolic $\mathrm{Ca}^{2+}$ concentrations were calculated by the ratio method of Grynkiewicz et al. (33). For comparison of patients and controls, $\mathrm{Ca}^{2+}$ mobilization was calculated as the area under the curve. This method takes into account both peak height and the rate of recovery, and thus more faithfully represents the extent and time over which $\mathrm{Ca}^{2+}$ was elevated.

$\mathrm{O}_{2}^{-}$generation. The generation of $\mathrm{O}_{2}^{-}$by neutrophils and monocytes was measured as superoxide dismutase-inhibitable cytochrome $c$ reduction by a continuous recording spectrophotometric method (34). Cells were preincubated for $5 \mathrm{~min}$ at $37^{\circ} \mathrm{C}$ before addition of stimulus. $\mathrm{O}_{2}^{-}$generation was monitored for 1 min before addition of ligand to obtain baseline rate. After addition of either f-Met-Leu-Phe or PMA, $\mathrm{O}_{2}^{-}$generation was monitored for $4 \mathrm{~min}$. The results are expressed as average rate or average amount of $\mathrm{O}_{2}^{-}$production in units of $\mathrm{nmol} \mathrm{O}{ }_{2}^{-} / \mathrm{min} /$ $10^{6}$ cells or nmol $\mathrm{O}_{2}^{-} / 10^{6}$ cells, respectively.

Analysis of $C D 11 b$ receptor regulation. Immunofluorescence detection of the CD11b expression was assessed by using the MAb OKM1 (anti-CD1 1b/CR3; Ortho Diagnostic Systems, Inc., Westwood, MA). Whole blood, collected in EDTA-treated monovette syringes, was placed on ice. After addition of f-Met-LeuPhe $\left(10^{-6} \mathrm{M}\right)$, whole blood was immediately transferred to a $37^{\circ} \mathrm{C}$ shaking water bath. Aliquots were removed at various timed intervals, the reaction was stopped through dilution with PBS + $0.01 \% \mathrm{NaN}_{3}+0.1 \% \mathrm{BSA}$ at $4^{\circ} \mathrm{C}$, and the aliquots were washed one time. The sampled blood was incubated with positive and irrelevant isotype control MAb (1:5 dilution) for $30 \mathrm{~min}$ at $4^{\circ} \mathrm{C}$, washed twice with PBS $+0.01 \% \mathrm{NaN}_{3}+0.1 \% \mathrm{BSA}$, and incubated with FITC-conjugated goat $\mathrm{F}\left(\mathrm{ab}^{\prime}\right)_{2}$ anti-mouse immunoglobulin (1:80 dilution; Tago, Burlingame, CA) for $30 \mathrm{~min}$. After lysis of red blood cells, cell preparations were analyzed by flow cytometry (Epics C, Coulter Electronics, Inc., Hialeah, FL) as previously described (31). Individual cells from monocyte and neutrophil populations were selectively gated based on forward and right-angle light scatter.

Neutrophil chemotaxis assay. Neutrophil chemotaxis was determined by the agarose method (35). Chemotaxis plates were prepared with $1.2 \%$ agarose containing $10 \%$ pooled human serum in modified Eagle's medium. Cells were placed in a central well and $10 \mu \mathrm{L}$ of attractant were added to an adjoining well. Plates were incubated $2 \mathrm{~h}$ at $37^{\circ} \mathrm{C}$ in $5 \% \mathrm{CO}_{2}$, then fixed with methanol and formalin. Agarose was removed, and the plates were stained with Wright's stain. Chemotaxis was determined by measuring the distance from the leading front to the central well and subtracting the distance that the cells moved in the opposite direction. Measurements were obtained using an overhead projection microscope with $40 \times$ magnification.

Materials. rhG-CSF (sp act $=1 \times 10^{8} \mathrm{U} / \mathrm{mg}$ of protein) was obtained from Amgen and rhGM-CSF (sp act $=1 \times 10^{8} \mathrm{U} / \mathrm{mg}$ ) was obtained from Genzyme (Cambridge, MA). PMA and fMet-Leu-Phe were purchased from Sigma Cemical Co. (St. Louis, MO). PMA was stored as a concentrated stock solution in DMSO and f-Met-Leu-Phe in ethanol. Both PMA and f-Met-Leu-Phe were diluted in buffer before use.

\section{RESULTS}

Effect of G-CSF administration on peripheral blood counts. Figure 1 shows the effect of G-CSF therapy on circulating levels of neutrophils and eosinophils. Before the start of G-CSF therapy, the patient's ANC was $336 / \mathrm{mm}^{3}$. G-CSF treatment resulted in a prompt increase in mature circulating neutrophils to 1333 by d 2 of therapy. The patient's ANC remained within the normal range during 8 mo of treatment with an average ANC of 2842 with cell counts fluctuating between 736 and $11790 / \mathrm{mm}^{3}$. The G-CSF therapy selectively increased only the levels of peripheral blood neutrophils. The number of circulating eosinophils during G-CSF therapy was not significantly different from pre-G-CSF therapy levels (Fig. 1).

An unexpected side effect of G-CSF therapy is depicted in Figure 2, which shows the patient's platelet count both before and after G-CSF therapy. Before G-CSF therapy, the patient had an elevated platelet count. This is a common observation in patients with GSD $1 \mathrm{~b}$, and the reason for this elevation is not 


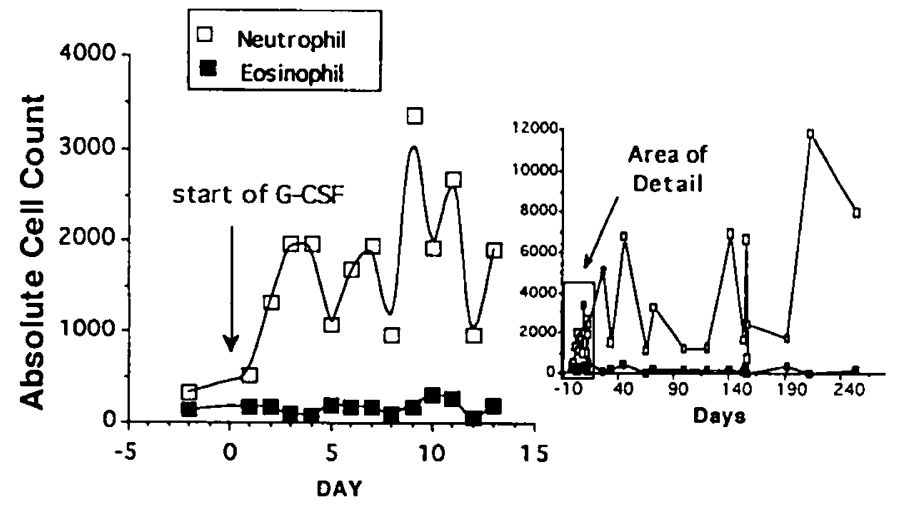

Fig. 1. Neutrophil and eosinophil absolute cell counts during G-CSF therapy. Time course of ANC and absolute eosinophil counts in response to G-CSF $(5 \mu \mathrm{g} / \mathrm{kg} / \mathrm{d})$ therapy. Inset details cell counts followed for 8 mo of therapy.

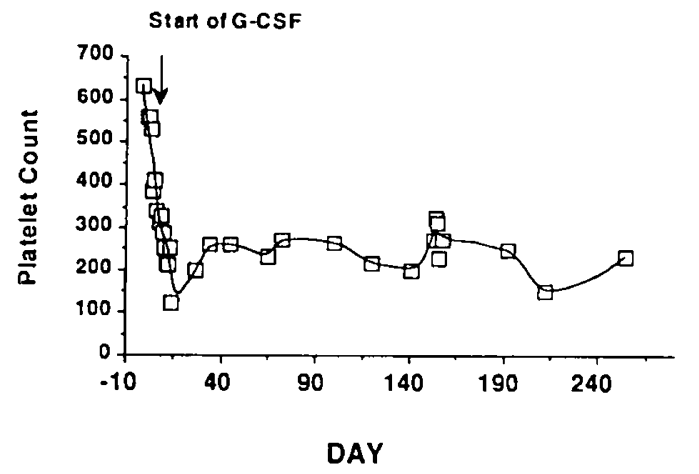

Fig. 2. Platelet count during G-CSF therapy. Time course of platelet count in response to G-CSF $(5 \mu \mathrm{g} / \mathrm{kg} / \mathrm{d})$ therapy.

known (12). Interestingly, G-CSF therapy resulted in a reduction of the patient's platelet count to values that stabilized within the normal range.

In vitro and in vivo effects of $\mathrm{G}-\mathrm{CSF}$ on $\mathrm{O}_{2}{ }^{-}$production and $\mathrm{Ca}^{2+}$ mobilization. G-CSF therapy resulted in significant improvement in the levels of circulating neutrophils, which was coupled with clinical improvement with a decrease in both the rate of infection and the severity of illness. In addition to neutropenia, we previously documented depressed respiratory burst activity in neutrophils and monocytes from GSD $1 \mathrm{~b}$ patients $(18,19,36)$. We next determined whether G-CSF also corrected the respiratory burst defect in GSD $1 \mathrm{~b}$ phagocytic cells.

In vitro cytokine effects on neutrophil $\mathrm{O}_{2}^{-}$generation. To establish whether in vivo use of cytokines would be appropriate for the treatment of the depressed $\mathrm{O}_{2}^{-}$generation in GSD $1 \mathrm{~b}$ and to determine whether short-term exposure could alter neutrophil function in GSD $1 \mathrm{~b}$, we first tested these cytokines in vitro. Before G-CSF therapy, the in vitro effects of G-CSF on $10^{-7} \mathrm{M}$ f-Met-Leu-Phe-triggered $\mathrm{O}_{2}^{-}$generation were determined in isolated neutrophils from three unrelated GSD Ib patients. As shown in Figure 3, control neutrophils stimulated by f-Met-Leu-Phe produced $\mathrm{O}_{2}^{-}$at a rate of $1.03 \pm 0.10 \mathrm{nmol} /$ $\min / 10^{6}$ cells (mean $\pm \mathrm{SD}, n=$ duplicate determinations of three patients with matched controls). In contrast, neutrophils from GSD $1 \mathrm{~b}$ patients generated $\mathrm{O}_{2}{ }^{-}$at a rate significantly less than controls $\left(0.36 \pm 0.04 \mathrm{nmol} / \mathrm{min} / 10^{6}\right.$ cells, $\left.p<0.01\right)$. When control neutrophils were incubated with G-CSF $\left(5 \times 10^{5} \mathrm{U} / \mathrm{L}\right)$ $15 \mathrm{~min}$ before the addition of $\mathrm{f}-\mathrm{Met}$-Leu-Phe, the rate of $\mathrm{O}_{2}^{-}$ generation was significantly increased to $2.31 \pm 0.41 \mathrm{nmol} / \mathrm{min} /$ $10^{6}$ cells $(p<0.01)$. The addition of G-CSF to GSD $1 \mathrm{~b}$ neutrophils increased the rate of $\mathrm{O}_{2}{ }^{-}$production by 2 -fold $(0.61 \pm 0.06$ $\mathrm{nmol} / \mathrm{min} / 10^{6}$ cells, $p<0.01$ ) (Fig. $3 A$ ). However, the rate was still significantly below control values obtained with or without G-CSF pretreatment $(p<0.01)$.
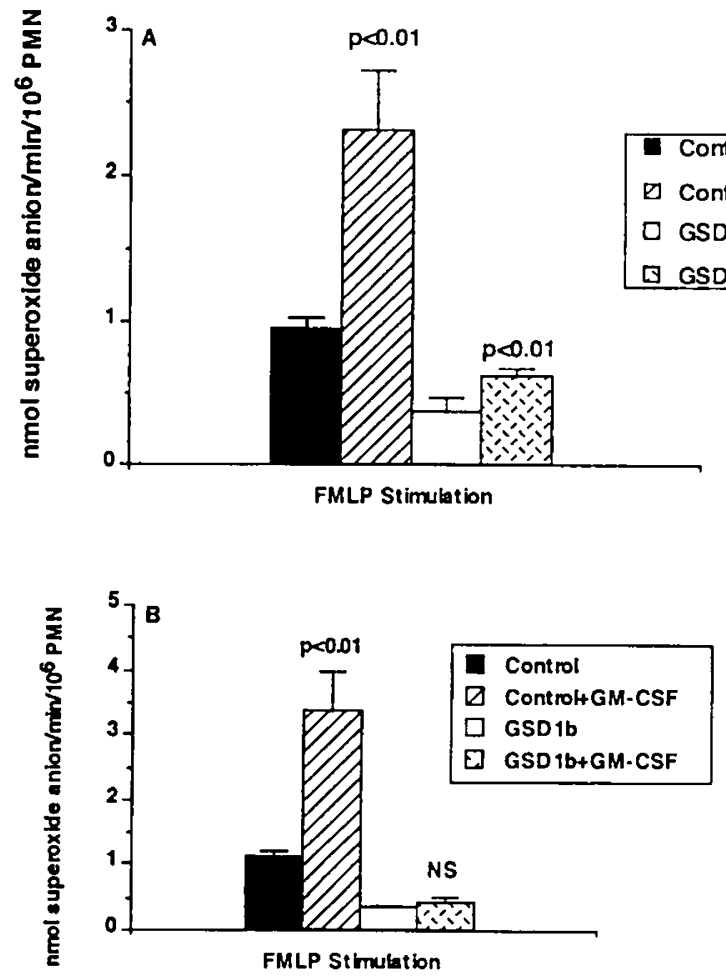

Fig. 3. Effect of G-CSF and GM-CSF pretreatment in vitro on $\mathrm{O}_{2}{ }^{-}$ production in control and GSD $\mathrm{lb}$ neutrophils. The time course of superoxide generation was determined in freshly isolated neutrophils as superoxide dismutase-inhibitable cytochrome $c$ reduction by continuous recording spectrophotometric technique. Neutrophils $\left(1 \times 10^{9} / \mathrm{L}\right)$ from control and GSD $1 \mathrm{~b}$ patients were incubated for $15 \mathrm{~min}$ with $5 \times 10^{5}$ $\mathrm{U} / \mathrm{L}$ G-CSF $(A)$ or $1.25 \times 10^{5} \mathrm{U} / \mathrm{L}$ GM-CSF $(B)$ before addition of $10^{-6}$ $\mathrm{M}$ f-Met-Leu-Phe. Values are mean \pm SEM of duplicate determinations for three individual patients with matched controls.

The effect of GM-CSF on $\mathrm{O}_{2}{ }^{-}$production in neutrophils from controls and GSD $1 \mathrm{~b}$ patients was also compared. As shown in Figure $3 B$, addition of GM-CSF $\left(1.25 \mathrm{U} \times 10^{5} / \mathrm{L}\right) 15 \mathrm{~min}$ before stimulation with $\mathrm{f}-\mathrm{Met}-\mathrm{Leu}-\mathrm{Phe}$ significantly increased $\mathrm{O}_{2}{ }^{-}$production in control neutrophils to $3.36 \pm 0.62 \mathrm{nmol} / \mathrm{min} / 10^{6}$ cells $(p<0.01)$. In contrast, the addition of GM-CSF to GSD lb neutrophils before stimulation with $\mathrm{f}-\mathrm{Met}$-Leu-Phe did not produce an enhanced respiratory burst (Fig. $3 B$ ).

In vitro cytokine effects on neutrophil $\mathrm{Ca}^{2+}$ mobilization. We have shown previously that the depressed rate of f-Met-Leu-Phetriggered $\mathrm{O}_{2}{ }^{-}$production by GSD $\mathrm{lb}$ neutrophils was associated with decreased $\mathrm{Ca}^{2+}$ mobilization $(18,19)$. We determined the effects of G-CSF and GM-CSF pretreatment on $\mathrm{Ca}^{2+}$ mobilization in neutrophils from control donors and GSD $1 \mathrm{~b}$ patients. As previously reported (25), G-CSF $\left(5 \times 10^{5} \mathrm{U} / \mathrm{L}\right)$ itself did not trigger calcium mobilization in control neutrophils. Moreover, preincubation of control neutrophils with G-CSF for $15 \mathrm{~min}$ did not enhance f-Met-Leu-Phe $\left(10^{-7} \mathrm{M}\right)$-triggered $\mathrm{Ca}^{2+}$ mobilization (Fig. 4A). In agreement with our previous studies (18, 19), $\mathrm{Ca}^{2+}$ mobilization was reduced in GSD $1 \mathrm{~b}$ neutrophils in response to $10^{-7} \mathrm{M}$ f-Met-Leu-Phe compared with controls (Fig. 4). Preincubation with G-CSF (Fig. 4B) did not correct the reduced calcium mobilization to f-Met-Leu-Phe stimulation in GSD $1 \mathrm{~b}$ neutrophils. Pretreatment of neutrophils with GM-CSF $\left(1.25 \times 10^{5} \mathrm{U} / \mathrm{L}\right)$ did not trigger $\mathrm{Ca}^{2+}$ mobilization nor did it enhance f-Met-Leu-Phe-stimulated $\mathrm{Ca}^{2+}$ mobilization (data not shown).

Effect of in vivo G-CSF administration on neutrophil $\mathrm{O}_{2}^{-}$ generation and $\mathrm{Ca}^{2+}$ mobilization. The effects of G-CSF on neutrophil functions in vivo were determined by obtaining blood samples at various time intervals during therapy and then measuring the rate of $\mathrm{O}_{2}^{-}$generation and $\mathrm{Ca}^{2+}$ mobilization in re- 

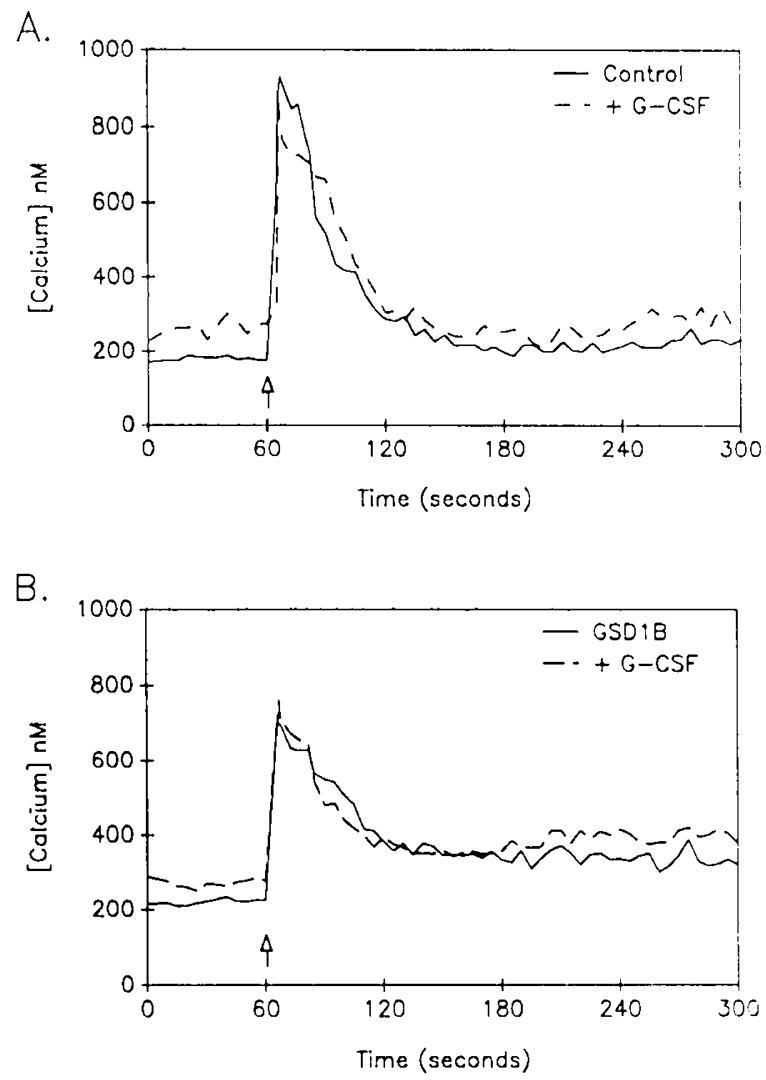

Fig. 4. Effect of in vitro G-CSF pretreatment on $\mathrm{Ca}^{2+}$ mobilization in neutrophils. Time course of changes in cytosolic calcium in neutrophils from control $(A)$ and GSD $1 \mathrm{~b}$ patient $(B)$ in response to stimulation with f-Met-Leu-Phe. Cells were preincubated in the absence or presence of $5 \times 10^{5} \mathrm{U} / \mathrm{L} \mathrm{G}-\mathrm{CSF}$ for $15 \mathrm{~min}$ at $37^{\circ} \mathrm{C}$ before stimulation with $10^{-7}$ $\mathrm{M}$ f-Met-Leu-Phe. Alterations in cytosolic calcium were monitored as changes in fluorescence of fura-2-loaded cells.

Table 1. Effect of in vivo G.CSF therapy on GSD $1 b$ neutrophil functions*

\begin{tabular}{ccc}
\hline $\begin{array}{c}\text { Time on G-CSF } \\
\text { therapy }\end{array}$ & $\begin{array}{c}\mathrm{O}_{2}^{-} \text {production } \\
\text { (\% of control) }\end{array}$ & $\begin{array}{c}\mathrm{Ca}^{2+} \text { mobilization } \\
\text { (\% of control) }\end{array}$ \\
\hline Pretherapy & 27 & 38 \\
Mo 2 & 52 & 44 \\
Mo 4 & 109 & 94 \\
\hline
\end{tabular}

* Effect on $\mathrm{O}_{2}^{-}$production and $\mathrm{Ca}^{2+}$ mobilization in GSD $1 \mathrm{~b}$ neutrophils in response to stimulation with $10^{-7} \mathrm{M}$ f-Met-Leu-Phe.

sponse to f-Met-Leu-Phe. Before G-CSF therapy, the patient's neutrophil $\mathrm{O}_{2}{ }^{-}$production in response to f-Met-Leu-Phe was 19 $\pm 13 \%$ of controls (mean $\pm \mathrm{SD}, n=3$ separate neutrophil preparations). As shown in Table 1, after 2 mo of G-CSF therapy, f-Met-Leu-Phe-triggered $\mathrm{O}_{2}^{-}$production had improved to approximately $50 \%$ of control values. There was also a small improvement in $\mathrm{Ca}^{2+}$ mobilization. By $4 \mathrm{mo}$, there was a dramatic improvement in both $\mathrm{O}_{2}^{-}$production and $\mathrm{Ca}^{2+}$ mobilization to values similar to controls (Table 1).

We previously reported that $\mathrm{O}_{2}^{-}$generation in response to other ligands, such as PMA, was also reduced in GSD $1 \mathrm{~b}$ neutrophils $(18,19)$. However, after 4 mo of G-CSF therapy, $\mathrm{O}_{2}^{-}$ production stimulated by PMA $(0.1 \mathrm{mg} / \mathrm{L})$ was also corrected in GSD $1 \mathrm{~b}$ neutrophils $\left(1.36 \pm 0.74 \mathrm{nmol} \mathrm{O}_{2}^{-} / \mathrm{min} / 10^{6} \mathrm{GSD} \mathrm{lb}\right.$ neutrophils versus $1.22 \pm 0.28 \mathrm{nmol} \mathrm{O}_{2}^{-} / \mathrm{min} / 10^{6}$ control neutrophils, respectively, $n=2$ separate neutrophil preparations, $p$ $=$ NS).

Effect of in vivo G-CSF administration on monocyte $\mathrm{O}_{2}^{-}$ generation. Although the number of circulating monocytes is not reduced in GSD $1 \mathrm{~b}$ patients, these phagocytic cells also have defective respiratory burst activity $(14,18)$. Although G-CSF receptors are located primarily on neutrophils, they have been shown on monocytes as well (37). We next determined whether in vivo G-CSF treatment would also correct the defective respiratory burst activity in circulating monocytes. Before G-CSF therapy, respiratory burst activity in GSD lb monocytes was depressed in response to f-Met-Leu-Phe (32\% of control) and PMA $(43 \%$ of control) $(18,19)$. By comparison, after 8 mo of G-CSF therapy, GSD $1 \mathrm{~b}$ monocyte $\mathrm{O}_{2}^{-}$production was similar to that of controls when stimulated with either $10^{-6} \mathrm{M}$ f-MetLeu-Phe $\left(2.53 \pm 0.21 \mathrm{nmol} \mathrm{O}_{2}^{-} / 10^{6}\right.$ GSD $1 \mathrm{~b}$ cells and $3.48 \pm$ $0.40 \mathrm{nmol}{ }_{2}^{-} / 10^{6}$ control cells, mean $\left.\pm \mathrm{SD}, n=2\right)$ or $0.1 \mathrm{mg} /$ L PMA $\left(10.71 \pm 4.10 \mathrm{nmol} \mathrm{O}_{2}^{-} / 10^{6}\right.$ GSD $\mathrm{lb}$ cells and $10.57 \pm$ $1.68 \mathrm{nmol} \mathrm{O}_{2}^{-} / 10^{6}$ control cells, $n=2$ ).

Effect of in vivo G-CSF administration on neutrophil chemotaxis. Defective chemotaxis was previously documented in neutrophils from this GSD $1 \mathrm{~b}$ patient $(15)$ and has been reported in neutrophils from other GSD $1 \mathrm{~b}$ patients $(8,16)$. After 8 mo of G-CSF therapy, random and directed neutrophil migration toward f-Met-Leu-Phe was examined. Table 2 summarizes results of neutrophil chemotaxis experiments performed during G-CSF therapy. The random migration of patient neutrophils was diminished to $46-50 \%$ of control. The directed migration of GSD lb neutrophils toward $5 \times 10^{-8} \mathrm{M}$ and $10^{-7} \mathrm{M}$ f-Met-Leu-Phe was $33 \%$ and $44 \%$ of control values, respectively. Thus, chemotaxis remained abnormal during G-CSF therapy.

Effect of in vivo G-CSF administration neutrophil CD $11 b$ cell surface expression. We next evaluated the possible relationship between defective chemotaxis and cell surface expression and/or up-modulation of CD $11 \mathrm{~b}$ (C3bi receptor). CD $1 \mathrm{lb}$ is a surface glycoprotein that is part of a family of leukocyte adhesion proteins that are essential for adhesion-dependent granulocyte functions such as chemotaxis, aggregation, adherence to endothelial cells, and phagocytosis $(38-40)$. The expression of CD $11 \mathrm{~b}$ antigen on control and GSD $1 \mathrm{~b}$ neutrophils stimulated with $10^{-6} \mathrm{M}$ f-Met-Leu-Phe were compared. After G-CSF therapy, the constitutive expression of CD $11 \mathrm{~b}$ on GSD $1 \mathrm{~b}$ neutrophils was similar to that of controls (Fig. 5). F-Met-Leu-Phe stimulation of GSD $1 \mathrm{~b}$ neutrophils produced an up-modulation of CD $11 \mathrm{~b}$ expression that was comparable in magnitude to that of control neutrophils (Fig. 5). There was, however, a difference in the rate of up-modulation of CD $11 \mathrm{~b}$ expression in GSD $1 \mathrm{~b}$ neutrophils compared with control cells. During G-CSF therapy, half maximal up-regulation of $C D 11 \mathrm{~b}$ occurred within $1.5 \mathrm{~min}$ in neutrophils from the GSD $1 \mathrm{~b}$ patient compared with $5 \mathrm{~min}$ in control cells. Before G-CSF therapy, both CD 11 b expression and the rate of receptor up-regulation in response to f-Met-LeuPhe were not significantly different from controls (data not shown).

Table 2. Effect of in vivo G-CSF therapy on GSD $1 b$ neutrophil chemotaxis to f-Met-Leu-Phe*

\begin{tabular}{lccc}
\hline $\begin{array}{c}\text { Stimulus/type } \\
\text { of migration }\end{array}$ & Control $(\mathrm{mm})$ & Patient $(\mathrm{mm})$ & $\begin{array}{c}\text { Significance } \\
\text { (control } v s \\
\text { patient) }\end{array}$ \\
\hline $5.0 \times 10^{-8} \mathrm{M}$ f-Met-Leu-Phe & & \\
Leading front & $3.7 \pm 0.3(n=5)$ & $1.4 \pm 0.9(n=6)$ & $p<0.001$ \\
Spontaneous & $1.3 \pm 0.3(n=5)$ & $0.6 \pm 0.2(n=6)$ & $p<0.001$ \\
Specific & $2.4 \pm 0.4(n=5)$ & $0.8 \pm 0.8(n=6)$ & $p<0.004$ \\
$1.0 \times 10^{-7} \mathrm{M}$ f-Met-Leu-Phe & & \\
Leading front & $6.0 \pm 1.0(n=6)$ & $2.7 \pm 1.3(n=6)$ & $p<0.001$ \\
Spontaneous & $1.0 \pm 0.3(n=6)$ & $0.5 \pm 0.0(n=6)$ & $p<0.003$ \\
Specific & $5.0 \pm 1.1(n=6)$ & $2.2 \pm 1.3(n=6)$ & $p<0.002$ \\
\hline
\end{tabular}

* Values are expressed as mean \pm SD. Specific migration values were calculated from two individual trials done in duplicate and triplicate by subtracting the random migration from the leading front migration. Significance was determined by $t$ test. 


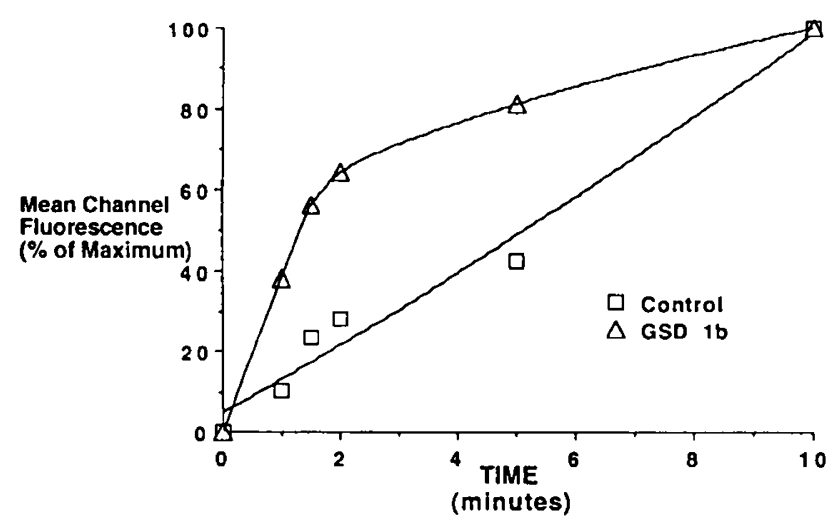

Fig. 5. Effect of in vivo G-CSF administration on CD $11 \mathrm{~b}$ expression. Time course of the increase in expression of CD $11 \mathrm{~b}$ in response to $10^{-6}$ $\mathrm{M}$ f-Met-Leu-Phe. Neutrophils were incubated for $15 \mathrm{~min}$ with $10^{-6} \mathrm{M}$ f-Met-Leu-Phe as described in Materials and Methods. Results are expressed as \% where maximal expression was taken to be the mean channel fluorescence of $0.1 \mathrm{mg} / \mathrm{L}$ PMA-stimulated cells at $15 \mathrm{~min}$ and $0 \%$ was taken to be the constitutive expression of $C D 11 \mathrm{~b}$ of control neutrophils (time 0 ).

\section{DISCUSSION}

Patients with GSD $1 \mathrm{~b}$ are distinguished from patients with other forms of GSD by neutropenia, phagocytic cell dysfunction, and recurrent bacterial infections. The neutropenia in GSD $1 \mathrm{~b}$ patients is variable, but ANC are usually less than $500 / \mathrm{mm}^{3}$. The underlying cause of neutropenia is not known but is thought to be either impaired maturation or ineffective mobilization of the cells into the circulation $(11,12)$. Before G-CSF therapy, the myeloid cells in our patient were increased in the bone marrow and were morphologically normal, with an increase in band forms (data not shown). In agreement with previous studies (4143), the neutropenia associated with GSD $1 \mathrm{~b}$ was corrected rapidly with administration of G-CSF. The quick response (within 2-3 d) to this therapy suggests that G-CSF triggers demargination of neutrophils into the circulation rather than stimulation of early myeloid precursors, which would require a longer response time such as in the treatment of severe congenital neutropenia $(28,29,44,45)$.

In contrast to the other studies on GSD lb patients, fluctuations in the neutrophil levels were observed in this patient over the course of G-CSF treatment (41-43). The reason for these fluctuations is not clear, and before G-CSF therapy the patient did not demonstrate cyclic neutropenia. This type of fluctuation has been observed in some but not all patients with severe congenital neutropenia receiving G-CSF therapy $(44,45)$; however, the basis for the oscillations in this patient population is not known.

G-CSF therapy also reduced the elevated platelet counts observed in this patient to levels within the normal range. This effect of G-CSF therapy on platelets has been observed in patients with congenital agranulocytosis who have elevated platelet counts in the absence of documented infection (44). It is not clear whether the drop in platelet counts is due to a decrease in infections or a direct effect of G-CSF resulting in either an inhibition of platelet synthesis or an increase in platelet consumption.

In addition to neutropenia, defective respiratory burst activity and chemotaxis have been reported in both circulating phagocytes and adherent macrophages from GSD $1 \mathrm{~b}$ patients $(9,10$, $13-15,18,19,36)$. We demonstrated previously that the respiratory burst abnormality was associated with impaired $\mathrm{Ca}^{2+}$ mobilization and decreased $\mathrm{Ca}^{2+}$ stores $(18,19)$. The alteration in $\mathrm{Ca}^{2+}$ mobilization is an indication of an impairment in signaling in phagocytic cells from GSD $1 \mathrm{~b}$ patients; however, the specific defect has not been identified.
Both G-CSF and GM-CSF are capable of enhancing the responsiveness of mature cells of the immune system $(20,21,46)$. Therefore, we determined whether either of these growth factors could correct the respiratory burst defect in GSD lb phagocytes. In vitro, neutrophils from GSD $1 \mathrm{~b}$ patients respond with increased $\mathrm{O}_{2}^{-}$generation after short-term preincubation with GCSF but not with GM-CSF. In vivo, G-CSF therapy resulted in normalized neutrophil $\mathrm{O}_{2}{ }^{-}$production to ligand (i.e. f-Met-LeuPhe) and PMA simulation. This finding is in agreement with the studies of Schroten et al. (41). In addition, the defective $\mathrm{Ca}^{2+}$ mobilization increased concomitantly with the respiratory burst activity, suggesting that these two defects are directly related.

Distinct from previous studies on the effects of G-CSF therapy on GSD $1 \mathrm{~b}$ neutrophil function (41), we have detected a difference between the time courses necessary for correction of the neutropenia and for correction of the respiratory burst activity through in vivo G-CSF therapy. Neutropenia was corrected within several days, but G-CSF therapy resulted in only a gradual correction of neutrophil function that took several months to attain control levels. This suggests that G-CSF is acting in multiple ways during hematopoiesis.

In vivo, G-CSF may correct the respiratory burst through a direct action on mature granulocytes, possibly through some type of priming mechanism. The precise mechanism of neutrophil priming by G-CSF has not been elucidated. G-CSF does not appear to act directly on the f-Met-Leu-Phe receptor, rather it works through activation of a signal transduction pathway that is distinct from those that increase cytosolic $\mathrm{Ca}^{2+}$ and activate protein kinase $C(24,25,27)$. Sullivan et al. (25) proposed that enhanced respiratory burst activity in response to pretreatment with G-CSF may be a result of increased arachidonate metabolism and the accumulation of its metabolites. It should be noted, however, that although in vitro G-CSF pretreatment significantly increased the rate of $\mathrm{O}_{2}{ }^{-}$production in GSD $1 \mathrm{~b}$ neutrophils, the rate was still significantly less than that in controls. Moreover, we demonstrated that there was a parallel improvement in respiratory burst activity and $\mathrm{Ca}^{2+}$ mobilization during G-CSF therapy, although we could not increase $\mathrm{Ca}^{2+}$ mobilization in vitro with G-CSF. Furthermore, priming does not explain why it takes several months for the correction of the respiratory burst and the need for several generations of neutrophils to be exposed in vivo to G-CSF.

Alternatively, the depressed respiratory burst associated with impaired $\mathrm{Ca}^{2+}$ mobilization could be due to a subpopulation of cells with functional defects accompanied by a subset of neutrophils with functionally normal neutrophils. There is evidence that the defective $\mathrm{Ca}^{2+}$ mobilization we previously documented is the result of defective subpopulations of neutrophils $(18,19$, 47). Accordingly, raising the in vivo levels of G-CSF through therapy may select for differential proliferation of a lineage of cells with normal respiratory burst activity. Nevertheless, the therapeutic effects appear to act at the level of the progenitor cells and not directly on mature neutrophils.

Although G-CSF therapy corrected the neutropenia, as well as the defective respiratory burst activity and associated blunted $\mathrm{Ca}^{2+}$ mobilization, it did not correct the defect in chemotaxis. Thus, the depressed chemotaxis in GSD $1 \mathrm{~b}$ phagocytes appears to be distinct from the defect in respiratory burst activity and $\mathrm{Ca}^{2+}$ mobilization. Indeed, recent studies have suggested that chemotaxis will occur independently of a rise in intracellular $\mathrm{Ca}^{2+}(48)$. Decreased random and directed migration does not appear to be a result of altered expression of C3bi receptors, inasmuch as there are no significant differences compared with controls in either constitutive expression or f-Met-Leu-Phestimulated receptor expression during G-CSF therapy. G-CSF therapy did, however, alter the rate of up-modulation of C3bi receptor expression in response to f-Met-Leu-Phe. Previous studies on patients with congenital neutropenia and patients undergoing chemotherapy have demonstrated increased expression of neutrophil CD $1 \mathrm{ll}$ antigen with G-CSF therapy $(22,45)$. The 
increased rate of $\mathrm{C} 3 \mathrm{bi}$ receptor expression may result in hyperadhesiveness and consequently reduce the chemotactic response (24). Thus, any correction of the intrinsic chemotactic defect in GSD 1 b neutrophils may have been counteracted due to G-CSFmediated alterations in adherence.

In summary, multiple sites of dysfunction have been identified in phagocytic cells in GSD $1 \mathrm{~b}$ including chemotaxis, respiratory burst activity, and $\mathrm{Ca}^{2+}$ mobilization. At present, it is not known whether these phagocytic cell anomalies are a direct result of a primary translocase defect or a secondary effect due to either metabolic consequences or a more fundamental membrane defect. The results of this study demonstrate that cytokine therapy can correct both the neutropenia and the respiratory burst defect in GSD 1b. G-CSF increased the patient's circulating levels of neutrophils within a few days of therapy. G-CSF therapy also resulted in a gradual correction of the respiratory burst defect with parallel increased $\mathrm{Ca}^{2+}$ mobilization. Therefore, long-term exposure in vivo to G-CSF may be required for correction of both the neutropenia and impaired $\mathrm{O}_{2}^{-}$production in GSD $1 \mathrm{~b}$ patients. Finally, G-CSF therapy significantly reduced the incidence of bacterial infection in this patient, and she has not been hospitalized for the treatment of bacterial infections for more than 1 y since starting G-CSF therapy.

\section{REFERENCES}

1. Cori GT, Cori CF 1952 Glucose-6-phosphate of liver in glycogen storage disease. J Biol Chem 199:661-667

2. Howell RR, Williams JC 1983 The glycogen storage diseases. In: Stanbury JB, Wyngaarden JB, Fredrickson DS (eds) The Metabolic Basis of Inherited Disease, 5th Ed. McGraw-Hill, New York, pp 141-166

3. Senior B, Loridan L 1968 Studies of liver glycogenosis with particular reference to the metabolism of intravenously administered glycerol. N Engl J Med 279:958-965

4. Narisawa KY, Igarashi Y, Otomo H, Tada K 1978 A new variant of glycogen storage disease type I due to a defect in glucose-6-phosphate transport system. Biochem Biophys Res Commun 83:1360-1364

5. Lange AJ, Arion WJ, Beaudet AL 1980 Type lb glycogen storage disease is caused by a defect in the glucose-6-phosphate translocase of the microsomal glucose-6-phosphatase system. J Biol Chem 255:8381-8384

6. DiRocco MC, Borrone C, Dallegri F, Frumento G, Patrone F 1984 Neutropenia and impaired neutrophil function in glycogenosis type $1 \mathrm{~b}$. J Inherited Metab Dis 7:151-154

7. Schaub J, Heyne K 1983 Glycogen storage disease type lb. Eur J Pediatr 140:283-288

8. Beaudet AL, Anderson DC, Michels VV, Arion WJ, Lange AJ 1980 Neutropenia and impaired neutrophil migration in type $\mathrm{lb}$ glycogen storage disease. J Pediatr 97:906-910

9. Narisawa K, Ishizawa S, Okumura H, Tada K, Kuzuya T 1986 Neutrophil metabolic dysfunction in genetically heterogeneous patients with glycogen storage disease type 1 b. J Inherited Metab Dis 9:297-300

10. Seger R, Steinmann B, Tiefenauer L, Matsunaga T, Gitzelmann R 1984 Glycogenosis lb: neutrophil microbicidal defects due to impaired hexose monophosphate shunt. Pediatr Res 18:297-299

11. Bartram CR, Przyrembel H, Wendel U, Bremer HJ, Schaub J, Hass JR 1981 Glycogenosis type Ib complicated by severe granulocytopenia resembling inherited neutropenia. Eur J Pediatr 137:81-84

12. Ambruso DR, McCabe ERB, Anderson D, Beaudet A, Ballas L, Brandt IK, Brown B, Coleman R, Dunger DB, Falletta JM, Friedman HS, Haymond MW, Keating JP, Kinney TR, Leonard JV, Mahoney DH, Matalon R, Roe T, Simmons P, Slonim AE 1985 Infectious and bleeding complications in patients with glycogenosis Ib. Am J Dis Child 139:691-697

13. Gahr M, Heyne K 1983 Impaired metabolic function of polymorphonuclear leukocytes in glycogen storage disease $1 \mathrm{lb}$. Eur J Pediatr 140:329-330

14. Ueno N, Tomita M, Ariga T, Ohkawa M, Nagano S, Takahashi Y, Arashima S, Matsumoto $S 1986$ Impaired monocyte function in glycogen storage disease type 1b. Eur J Pediatr 145:312-314

15. Koven NL, Clark MM, Cody CS, Stanley CA, Baker L, Douglas SD 1986 Impaired chemotaxis and neutrophil function in glycogenosis type $1 \mathrm{~b}$. Pediatr Res 20:438-442

16. Anderson DC, Mace ML, Brinkley BR, Martin RR, Smith CW 1981 Recurrent infection in glycogenosis type lb: abnormal neutrophil motility related to impaired redistribution of adhesion sites. J Infect Dis 143:447-459

17. Bashan N, Hagai Y, Potashnik R, Moses SW 1988 Impaired carbohydrate metabolism of polymorphonuclear leukocytes in glycogen storage disease 1b. J Clin Invest 81:1317-1322

18. Kilpatrick L, Garty B-Z, Lundquist KF, Hunter K, Stanley CA, Baker L, Douglas SD, Korchak HM 1990 Impaired metabolic function and signaling defects in phagocytic cells in glycogen storage disease type $1 \mathrm{~b}$. J Clin Invest 86:196-202
19. Korchak HM, Garty B-Z, Stanley CA, Baker L, Douglas SD, Kilpatrick L 1993 Impairment of calcium mobilization in phagocytic cells in glycogen storage disease type 1b. Eur J Pediatr 152(Suppl 1):S39-S43

20. Dmetri GD, Griffin JD 1991 Granulocyte colony stimulating factor and its receptor. Blood 78:2791-2808

21. Gregory SH, Magee DM, Wing EJ 1991 The role of colony-stimulating factors in host defenses. Proc Soc Exp Biol Med 197:349-360

22. Ohsaka A, Kitagawa S, Sakamoto S, Miura Y, Takanashi N, Takaku F, Saito M 1989 In vivo activation of human neutrophil functions by administration of recombinant human granulocyte colony stimulating factor in patients with malignant lymphoma. Blood 74:2743-2748

23. Lindemann A, Herrmann F, Oster W, Haffner G, Meyenburg W, Souza LM Mertelsmann R 1989 Hematologic effects of recombinant human granulocyte colony-stimulating factor in patients with malignancy. Blood 74:26442651

24. Yuo A, Kitagawa S, Ohsaka A, Ohta M, Miyazono K, Okabe T, Urabe A, Saito M, Takaku F 1989 Recombinant human granulocyte colony stimulating factor as an activator of human granulocytes: potentiation of responses triggered by receptor mediated agonists and stimulation of $\mathrm{C} 3 \mathrm{bi}$ receptor expression and adherence. Blood 74:2144-2149

25. Sullivan R, Griffin JD, Simons ER, Schafer AI, Meshulam T, Fredette JP, Maas AK, Gadenne A-S, Leavitt JL, Melnick DA 1987 Effects of recombinant human granulocyte and macrophage colony-stimulating factors on signal transduction pathways in human granulocytes. J Immunol 139:3422 3430

26. Kitagawa S, Yuo A, Souza LM, Saito M, Miura Y, Takaku F 1987 Recombinant human granulocyte colony stimulating factor enhances superoxide release in human granulocytes stimulated by the chemotactic peptide. Biochem Biophys Res Commun 144:1143-1146

27. Balazovich KJ, Almeida HI, Boxer LA 1991 Recombinant human G-CSF and GM-CSF prime human neutrophils for superoxide production through different signal transduction mechanisms. J Lab Clin Med 1 18:576-584

28. Boxer LA, Hutchinson R, Emerson S 1992 Recombinant human granulocyte colony stimulating factor in the treatment of patients with neutropenia. Clin Immunol Immunopathol 62:S39-S46

29. Hammond WP, Price TH, Souza LM, Dale DC 1989 Treatment of cyclic neutropenia with granulocyte-colony stimulating factor. $\mathrm{N}$ Engl J Med 320:1306-1311

30. Boyum A 1968 Isolation of mononuclear cells and granulocytes from human blood. Scand J Clin Lab Invest (Suppl 21)97:77-89

31. Hassan NF, Campbell DE, Douglas SD 1986 Purification of human monocytes on gelatin-coated surfaces. J Immunol Methods 95:273-276

32. Korchak HM, Vosshall LB, Zagon G, Ljubich P, Rich AM, Weissmann G 1988 Activation of the neutrophil by calcium mobilizing ligands. I. A chemotactic peptide and the lectin concanavalin A stimulate superoxide anion generation but elicit different calcium movements and phosphoinositide remodeling. J Biol Chem 263:1 1090-11097

33. Grynkiewicz G, Poenie M, Tsien RY 1985 A new generation of calcium indicators with greatly improved fluorescence properties. J Biol Chem 260:3440-3450

34. Korchak HM, Weissmann G 1978 Changes in membrane potential of human granulocytes antecede the metabolic responses to surface stimulation. Proc Natl Acad Sci USA 75:3818-3822

35. Nelson RD, Quie PG, Simmons RL 1975 Chemotaxis under agarose: a new and simple method for measuring chemotaxis and spontaneous migration of human polymorphonuclear leukocytes and monocytes. J Immuno 115:1650-1656

36. McCawley LJ, Korchak HM, Cutilli JR, Stanley CA, Baker L, Douglas SD, Kilpatrick L 1993 Interferon-gamma corrects the respiratory burst defect in vitro in monocyte-derived macrophages from glycogen storage disease type lb. Pediatr Res 34:265-269

37. Nicola NA, Metcalf D 1985 Binding of ${ }^{125}$ I-labeled granulocyte colony stimulating factor to normal murine hematopoietic cells. J Cell Physiol 124:313321

38. Anderson DC, Miller LJ, Schmalsteig FC, Rothlein R, Springer TA 1986 Contributions of the Mac-1 glycoprotein family to adherence dependent granulocyte functions: structure-function assessments employing subunit specific monoclonal antibodies. J Immunol 137:15-27

39. Sanchez-Madrid F, Nagg JA, Robbins E, Simon P, Springer TA 1983 A human leukocyte differentiation antigen family with distinct alpha-subunit and common beta subunit: the lymphocyte-function-associated antigen (LFA-1), the C3bi complement receptor (OKMI/Macl), and the pl 150:95 molecule. J Exp Med 158:1785-1803

40. Zimmerman GA, McIntyre TM 1988 Neutrophil adherence to human endothelium in vitro occurs by CDw18 (Mol, MAC-/LFA-1/GP 150:95) glycoprotein dependent and independent mechanisms. J Clin Invest 81:531-537

41. Schroten H, Roesler J, Breidenbach T, Wendel U, Elsner J, Schweitzer S, Zeidler C, Burdach S, Lohmann-Matthes M-L, Wahn V, Welte K 1991 Granulocyte and granulocyte-macrophage colony stimulating factors for treatment of neutropenia in glycogen storage disease type $\mathrm{lb}$. J Pediatr 119:748-754

42. Roe TF, Coates TD, Thomas DW, Miller JH, Gilsanz V 1992 Brief report: treatment of chronic inflammatory bowel disease in glycogen storage disease type Ib with colony stimulating factor. $N$ Engl J Med 326:1666-1669

43. Wang WC, Crist WM, Ihle JN, Arnold BA, Keating JP 1991 Granulocyte colony-stimulating factor corrects the neutropenia associated with glycogen storage disease type 1 b. Leukemia 5:347-349 
44. Bonilla MA, Gillio AP, Ruggeiro M, Kernan NA, Brochstein JA, Abboud M, Fumagalli L, Vincent M, Gabrilove JL, Welte K, Souza LM, O'Reilly RJ 1989 Effects of recombinant human granulocyte colony-stimulating factor on neutropenia in patients with congenital agranulocytosis. $\mathrm{N}$ Engl $\mathrm{J}$ Med 320:1574-1580

45. Weston B, Todd RF III, Axtell R, Balazovich K, Stewart J, Locey BJ, MayoBond L, Loos P, Hutchinson R, Boxer LA 1991 Severe congenital neutropenia: clinical effects and neutrophil function during treatment with granulocyte colony stimulating factor. J Lab Clin Med 117:282-290

46. Monroy RL, Davis TA, MacVittie TJ 1990 Granulocyte-macrophage colony stimulating factor: more than a hemopoietin. Clin Immunol Immunopathol 54:333-346

47. Elsner J, Kaever V, Emmendörffer A, Breidenbach T, Lohmann-Matthes M-L, Roesler J 1992 Heterogeneity in the mobilization of cytoplasmic calcium by human polymorphonuclear leukocytes in response to AMP, C5a and IL-8/NAP-1. J Leukocyte Biol 51:77-83

48. Kuijpers TW, Hoogerwerf M, Roos D 1992 Neutrophil migration across monolayers of resting or cytokine-activated endothelial cells. Role of intracellular calcium changes and fusion of specific granules with the plasma membrane. J Immunol 148:72-77

\section{Announcement}

\section{Annual Meetings}

The American Pediatric Society, The Society for Pediatric Research, and The Ambulatory Pediatric Association will hold their annual meetings May 2-5, 1994 at the Washington State Convention and Trade Center, Seattle. For Further information, contact APS/SPR Association Headquarters, 141 Northwest Point Blvd., P.O. Box 675, Elk Grove Village, IL 60009-0675, phone (708) 427-0205, fax (708) 427-1305 or Ambulatory Pediatric Association, 6728 Old McLean Village, McLean, VA 22101, phone (703) 556-9222, fax (703) 556-8729. 